\title{
Discarded food and resource depletion
}

\author{
Jaime Martínez-Valderrama ${ }^{a}$, Emilio Guirado $^{a}$ and Fernando T. Maestre ${ }^{a, b}$
}

Food systems are permeated by perverse incentives which often lead to food being discarded before entering the market and to the depletion of natural resources. Tomato production in the water scarce province of Almeria, in Spain, illustrates the problem and highlights the urgent need for policies that ensure ethical and environmental sustainability standards.

Over one third of the food produced globally is not consumed ${ }^{1}$, of which approximately $14 \%$ corresponds to post-harvest loss ${ }^{2}$. In most high-income countries, the primary reason for this is to control prices that, due to excess of produce in the market, may fall below production costs $^{3}$. Furthermore, food being discarded is often produced unsustainably and contributes to the depletion of natural resources. Yet, some countries and supranational administrative units like the European Union (EU) offer subsidies to compensate farmers for losses associated with price fluctuations, often strengthening already extremely competitive sectors ${ }^{4}$.

The province of Almería in Andalusia, Spain illustrates these problems well. One of the main vegetable production centers in the world, its agricultural model became known as the "Almeriense economic miracle" ${ }^{5}$. Despite poor quality soils ${ }^{6}$ and one of the lowest per capita incomes in Spain in the $1950 \mathrm{~s}^{7}$, the arrival of greenhouse agriculture in the 1960s made it the core of the province's demographic and socio-economic development in recent decades, supporting most of Andalusia's international agri-food trade ${ }^{8}$.

The rise of horticulture

The 1960s saw successful tests to grow vegetables on sand mulch (or "enarenado") replacing calcareous crust saline soils in the coastal area of Almería. Technological improvements have helped overcome the limitations imposed by poor soils, strong and persistent winds and low rainfall ( $250 \mathrm{~mm} /$ year on average) ${ }^{9}$. Lack of water was solved by exploiting the groundwater, adapting to its high salt content, and establishing efficient irrigation systems which are now used in $99.9 \%$ of the greenhouse surface area ${ }^{10}$. Old rudimentary greenhouses, with a perforated plastic cover to allow rainwater collection, have been turned into state-of-the-art greenhouses with sophisticated climate control methods. Pumping equipment draws from depths of more than $400 \mathrm{~m}^{11}$, and an entire and booming agricultural research industry pivots around one of Europe's so-called 'market garden'12. In 2018/19, production grew by $6.4 \%$ relative to $2017 / 18$, reaching 3.7 million t of fresh produce grown on more than $58,600 \mathrm{ha}^{13}$.

Almería's greenhouses now concentrate $75 \%$ of the production of tomato for fresh consumption in Andalusia and correspond to half of Spain's production (Spain is the main producer in the EU, with $30 \%$ of the tota $\left.\left.\right|^{14}\right)$. Local farmers and politicians claim efficient and sustainable use of water resources, often stating that "every drop of water is used" - an expression from Spain's 1920s hydraulic policy based on the use of dams, aquifers and inter- 
basin water transfer to compensate for the natural water imbalances of the country and help its modernization ${ }^{15}$. Yet, since the first experimental plots back in the 1960s, total water consumption has increased substantially as a result of agricultural expansion.

Economic indicators have generally shown a favorable trend, including higher production value, larger cultivation area (Fig. 1a) and greater exports, especially to Germany, France and Poland (Fig. 1d). However, the latest available data (2018/19) have shown a drop in tomato production, one of the most representative crops in Almeria (7.3\% in area and $10.5 \%$ in volume), due to the poor results of the previous season. The fall in prices (17.2\%) and exports (4.5\% in volume and $9.4 \%$ in value) coincided with an increase in EU imports (10.1\%). Farmers in Almeria see their dominant position threatened as the European market share of countries such as Morocco increases (10.7\% increase in EU imports from this country). In the prevailing agro-industrial model, based on economies of scale and stability of prices and sales ${ }^{13}$, the prospect of recurrent falls in economic indicators makes it necessary to increase technological efforts towards greater efficiency and access to new water resources.
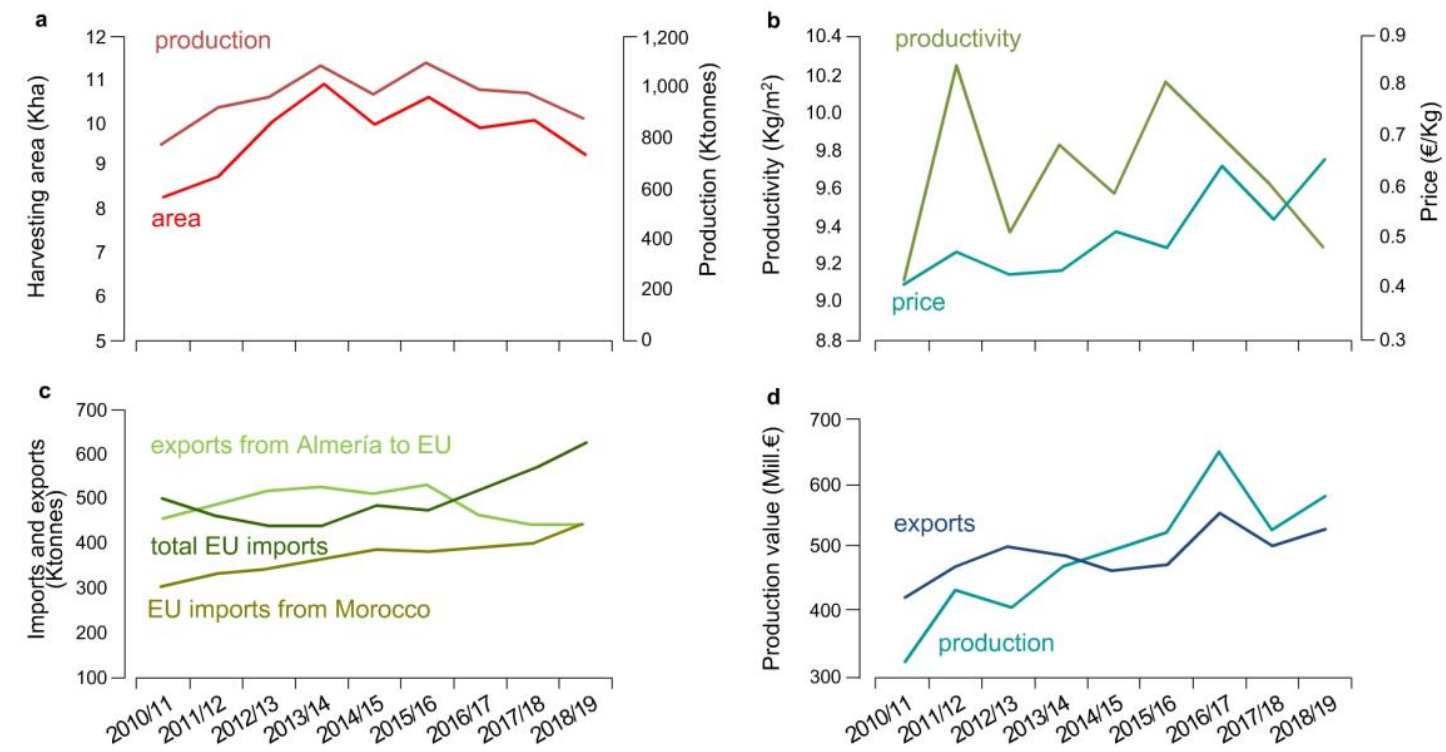

Fig. 1. Recent trends in Almeria's tomato production. (a) Cultivating area and production volume ${ }^{16}$. (b) Productivity and average price ${ }^{13,16}$. (c) Selected import-export figures ${ }^{17}$. (d) Production and export value $^{13}$.

Food loss and water depletion

The effects of reduced agricultural prices on farmers' incomes have often been alleviated by the partial destruction of the crop. To achieve national food security and support agricultural incomes, key aims of the European Common Agricultural Policy (CAP) are to safeguard farmers to make a reasonable living and deal with difficult market situations ${ }^{18}$. One of the instruments for achieving this is the withdrawal of up to $5 \%$ of the crop from the market ${ }^{4}$, which is paid by the EU at a maximum price of $339.6 \mathrm{EUR} / \mathrm{t}$ plus 18.2 - $108.3 \mathrm{EUR} / \mathrm{t}$ per transport (with a surcharge of $8.5 \mathrm{EUR} / \mathrm{t}$ if the transport is refrigerated) when it is for free distribution, and 254.8 EUR/t for any other destination (composting at best or destruction of the crop) ${ }^{19}$. Although part of the withdrawn harvest was diverted to food banks (49.1\%) or animal feed 
(7.4\%) in 2019 , a considerable part (43.5\%) was destroyed ${ }^{20}$, particularly during NovemberMarch when demand is highest.

Discarding food produced with so much effort, as producers claim, and in a territory with very limited water resources, maybe justifiable under exceptional circumstances (such as the Russia ban on imports of fresh fruit and vegetables from the EU in $2014^{3}$ ). Yet it is an ethically and environmentally reprehensible practice when it becomes commonplace. Only in 2019, more than $300,000 \mathrm{~m}^{3}$ of groundwater and $136.5 \mathrm{t}$ of fertilizers have been wasted, and more than $7,500 \mathrm{t}$ of $\mathrm{CO}_{2}$-eq have been emitted to the atmosphere through this practice in Andalusia which extends to other vegetables, like peppers, zucchinis and cucumbers (Fig. 2). It is noteworthy that the majority of these withdrawals correspond to Almeria, where $90 \%$ of the greenhouses in Andalusia are located ${ }^{13}$.

Poor management of water resources and overproduction in an increasingly saturated market are the main handicaps faced by farmers in Almería. The massive extraction of groundwater carried out in the last decades has deteriorated the aquifers both quantitatively and qualitatively $^{21}$. In Campo de Dalías, where most vegetable production is concentrated, the deterioration of the upper aquifer has forced the construction of wells of more than $150 \mathrm{~m}$ to reach the deep aquifer ${ }^{11}$. Seawater intrusion has elevated electrical conductivity above $6 \mathrm{dS} / \mathrm{m}$ in coastal areas ${ }^{22}$, which makes agriculture impossible for most crops (e.g. tomato and cucumber decrease their yield from $2 \mathrm{dS} / \mathrm{m})^{23}$. Additionally, the discharge of leachate ranges from 20 to $50 \%$ of the initial supply of 2,000-3,400 kg/ha of N-P-K fertilizers ${ }^{24}$, making these areas highly vulnerable to nitrate pollution. In terms of market saturation, Almería's farmers face competition from both within and outside the EU. On the one hand, the crop yield in the Netherlands $\left(55 \mathrm{~kg} / \mathrm{m}^{2}\right)$ is five times that of the area's greenhouses $\left(10 \mathrm{~kg} / \mathrm{m}^{2}\right)$. On the other hand, farmers claim that increased EU imports $(8,4 \% \text { in 2019 })^{17}$ from countries like Morocco or Senegal - considered unfair competitors because of their lax environmental standards and lower labor and production costs - reduce prices and exports (Fig. 1c).
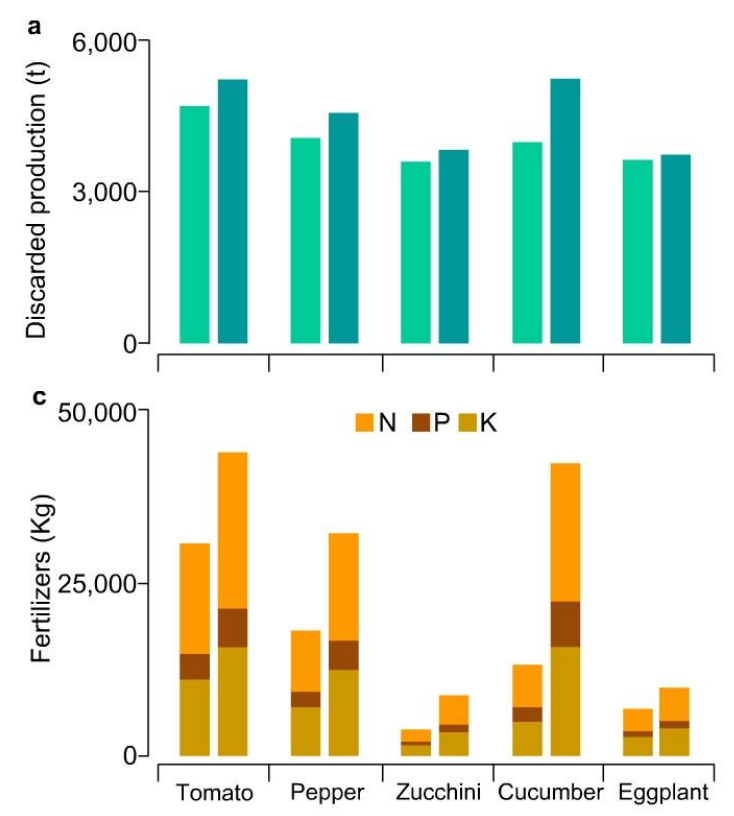
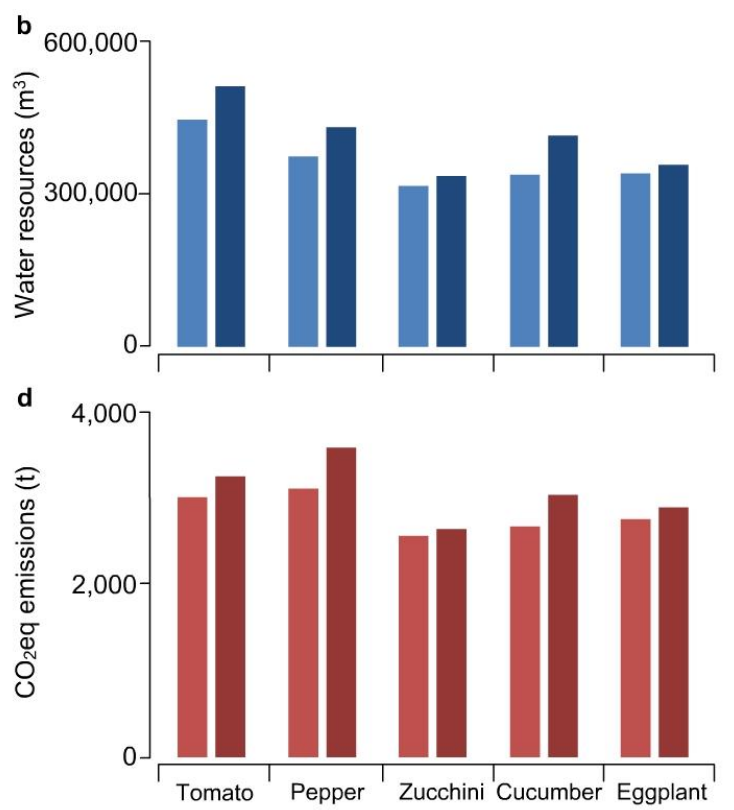
Fig. 2. Environmental impact associated with vegetables discarded in Andalusia in 2018 and 2019.

Discarded vegetables $^{20}(a)$ include the loss of water $^{25}(b)$, the loss fertilizers ${ }^{26,27}$ (c) and the emission of greenhouse gases ${ }^{28}(d)$ that could be avoided. Most of the Andalusian production of the analyzed crops is located in Almeria (100\% of pepper, zucchini and eggplant; $75 \%$ tomato; $65 \%$ cucumber).

Efforts aimed at alleviating negative effects of price shocks will not solve the multiple issues that are undermining the competitiveness of the agricultural sector in Almería and jeopardizing its future, such as the deterioration of water resources, the lack of local flagship products not available elsewhere ${ }^{29}$, or the opening of the EU to other markets. The reality is that a fundamental resource, water, is being depleted at an alarming rate in an already dry area where the effects of climate change are expected to be significant ${ }^{30}$. Signs of water scarcity should not be overlooked. Farmer decisions should not be based exclusively on the price of the product, which nowadays does not reflect water scarcity in the study area nor the carbon footprint of shipping the vegetables from Almería to elsewhere in Europe. Basic water indicators should also be considered, such as the exploitation rate (pumping vs. natural recharge ratio), the fall in piezometric levels or the increase of water salinity. Only with a proper management of available water resources can the sustainability of the agricultural sector be ensured.

\section{Moving forward}

The case of Almeria is not unique. In Spain alone, more than $114 \mathrm{kt}$ of fresh vegetables and fruits were discarded in 2019, although most of them (68.5\%) were distributed for free ${ }^{20}$. Fortunately, successive reforms of the CAP have contributed to food loss reduction (the volume discarded reached 2,018 kt yr ${ }^{-1}$ during the 1989 and 1996 period $^{2}$ ); still, it must be reduced further if we aim to achieve the United Nations Sustainable Development Goals (SDGs) - particularly SDG 2 ('Zero hunger') and target 12.3 ('Halve per capita global food waste at the retail and levels and reduce food losses') - while fostering a more sustainable, secure and equitable food production system ${ }^{31}$.

From an environmental sustainability perspective, measures to reduce the depletion of water resources are paramount along the entire food supply chain. On the production side, efforts must be made towards the internalization of externalities as well as farmers' full compliance with the legislation, such as the EU Water Framework, Nitrates and Biodiversity Directives. The few examples where groundwater-dependent agricultural systems are sustainable are those where, such as in the Clain Basin (France) ${ }^{32}$, a strict regulation is followed. This includes restricting the drilling of new wells, closing down illegal ones, regulating water extraction during the irrigation season, installing water meters on greenhouses, and conducting hydrogeological studies to refine the calculation of safe yield, i.e. the amount of water that can be withdrawn annually without affecting the quantity or quality of the groundwater. Although many of these measures were already foreseen in the Spanish Water Law of 1999 and have been ratified by the EU Water Framework, problems like the proliferation of illegal wells have persisted in major Spanish agricultural areas (e.g. Eastern La Mancha aquifer system, Campo de Cartagena, surroundings of the Doñana National Park $)^{33}$. It is key that farmers become aware of these sustainability issues, so that regulations are not interpreted as a punitive 
instrument but rather as a tool to better manage water resources and to ensure the sustainability of their activity.

On the consumption side, environmental awareness campaigns must continue, so that consumers can appreciate and decide whether to pay more for products that respect the environment (as many of them already do for organic products). Food labelling schemes related to nutrition, environmental and social responsibility are increasingly used ${ }^{34}$ and should also be considered; in the EU only, there are 174 initiatives related to environmental management and 182 to organic farming ${ }^{35}$. However, the current overload of labels and information may create confusion and make environmentally and socially conscious choices difficult. Although environmental and social responsibility labels are often considered less impactful than other product information and do not play a major role in food choice ${ }^{36}$, there is a growing interest in sustainability in the food sector. Specifically regarding water, there are labelling schemes that certify the efficiency of water use ${ }^{37}$ but not a quality label certifying that groundwater bodies are not being overexploited. This can be counterproductive if environmental sustainability continues to be seen through a productivist lens, concerned with profit maximization through resource efficiency gains as with drip irrigation technology ${ }^{29}$. In that sense, it seems more logical to opt for certifications that integrate various product attributes into a single label, including environmental (e.g., carbon and water footprint, impacts on biodiversity, use of organic farming) and social (e.g., fair trade and working conditions) factors.

From an economic perspective, a critical measure that could help reduce food waste - and which has been demanded by the primary sector for years - is to shorten the gap between the prices perceived by farmers and those paid by consumers ${ }^{38}$. In Spain, the increase between supermarkets and farm gate prices range from $642 \%$ for zucchini to $349 \%$ for cucumbers and $482 \%$ for tomatoes ${ }^{39}$. If part of the profit accrued by large distributors buying directly from farmer cooperatives or other intermediaries would be transferred to farmers, these may have enough margins to cover production costs without the need to produce as much as possible. Finally, we must not forget that integrating all aspects involved in agricultural production requires careful territorial planning to correctly allocate land uses and the implementation of effective policies protecting essential resources like water. The use of integrated models that simultaneously consider the evolution of groundwater and the socio-economic dynamics of the $a r e a^{40}$ can certainly help with this task. Governments should coordinate their actions on water, agriculture, climate change and land-use planning to address the environment-food production-health trilemma faced by societies in the 21st century, which is critical to ensure the sustainable development of our planet.

\section{Acknowledgments}

The authors are funded by the European Research Council grant agreement $n \circ 647038$ (BIODESERT). FTM acknowledges support from Generalitat Valenciana (CIDEGENT/2018/041). The authors appreciate the work of the reviewers who have helped to substantially improve this manuscript with their comments and suggestions. 


\title{
Author information
}

\author{
Affiliations \\ anstituto Multidisciplinar para el Estudio del Medio "Ramón Margalef", Universidad de \\ Alicante, Carretera de San Vicente del Raspeig s/n, 03690 San Vicente del Raspeig, Alicante, \\ Spain.

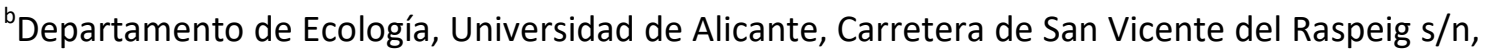 \\ 03690 San Vicente del Raspeig, Alicante, Spain.
}

\section{Corresponding author}

Jaime Martinez-Valderrama | e-mail: jaime.mv@ua.es

\section{Data availability}

Data are available at: https://doi.org/10.6084/m9.figshare.12053685.

\section{Ethics declaration \\ Conflict of interest}

The authors declare no competing interests.

\section{References}

1. FAO (Food and Agriculture Organization of the United Nations). Global food losses and food waste - Extent, causes and prevention. (2011).

2. FAO (Food and Agriculture Organization of the United Nations). The State of Food and Agriculture 2019. Moving forward on food loss and waste reduction. (2019).

3. Porter, S. D., Reay, D. S., Bomberg, E. \& Higgins, P. Sci. Total Environ. 631-632, 1544-1552 (2018).

4. DG-AGRI. The CAP in perspective: from market intervention to policy innovation (no. 1). Agricultural Policy Perspectives Briefs. (2011).

5. Tout, D. Geogr. J. 156, 304-312 (1990).

6. Sánchez-Picón, A., Aznar-Sánchez, J. A. \& García-Latorre, J. J. Arid Environ. 75, 1360-1367 (2011).

7. Downward, S. R. \& Taylor, R. J. Environ. Manage. 82, 277-289 (2007).

8. Valera, D. L., Belmonte, L. J., Molina-Aiz, F. D., López, A. \& Camacho, F. Acta Horticulturae 1170, (2017).

9. $\quad$ Lázaro, R., Rodrigo, F. S., Gutiérrez, L., Domingo, F. \& Puigdefábregas, J. J. Arid Environ. 48, 373395 (2001).

10. Céspedes, A. J., García, M. C., Pérez-Parra, J. J. \& Cuadrado, I. M. Caracterización de la Explotación Hortícola Protegida Almeriense. (Fundación para la Investigación Agraria en la Provincia de Almería (FIAPA). Cajamar, 2009).

11. IGME \& Junta de Andalucía. Sistema acuífero de la Sierra de Gádor y cuencas marginales. in Atlas Hidrogeológico de Andalucía 127-149 (Junta de Andalucia, 1998).

12. Aznar-Sánchez, J. A. \& Galdeano-Gómez, E. Open Geogr. J. 4, 103-114 (2011).

13. Cajamar. Análisis de la campaña hortofrutícola 2018/2019. (2020).

14. European Commission. The tomato market in the EU: Vol. 1: Production, areas and yields. (2019).

15. Swyngedouw, E. Environ. Hist. Camb. 20, 67-92 (2014).

16. Junta de Andalucía. Observatorio de precios y mercados [Price and Market Observatory]. (2020). Available at: https://www.juntadeandalucia.es/agriculturaypesca/observatorio/servlet/FrontController?ec=d efault. (Accessed: 2nd February 2020)

17. European Commission. Short-term Outlook for EU agricultural markets in 2019 and 2020. Edition $N^{\circ} 25$. (2019). 
18. European Commission. The common agricultural policy at a glance. (2020). Available at: https://ec.europa.eu/info/food-farming-fisheries/key-policies/common-agricultural-policy/capglance_en. (Accessed: 4th October 2020)

19. European Commission. Commission Delegated Regulation (EU) 2017/891 of 13 March 2017 supplementing Regulation (EU) No 1308/2013 of the European Parliament and of the Council with regard to the fruit and vegetables and processed fruit and vegetables sectors and supplementing Re. Off. J. Eur. Union L 138, 4-56 (2017).

20. FEGA. Fondo Español de Garantía Agraria. Ministerio de Agricultura, Pesca y Alimentación. Informe de retiradas en el marco de los programas operativos de las OPFH. Diciembre 2019. 22 (2019). Available at: https://www.fega.es/datos-campanas-clasificadas-por-sector/sector/Frutas y Hortalizas. (Accessed: 15th January 2020)

21. Junta de Andalucia. Adenda: trabajos necesarios para la mejora del conocimiento y protección contra la contaminación y el deterioro del estado de las masas de agua subterránea de las demarcaciones hidrográficas andaluzas de carácter intracomunitario, conforme a lo establecid. (Junta de Andalucia, 2011).

22. Sánchez-Martos, F., Pulido-Bosch, A., Molina-Sánchez, L. \& Vallejos-Izquierdo, A. Sci. Total Environ. 297, 43-58 (2002).

23. Maas, E. V. \& Hoffman, G. J. J. Irrig. Drain. Div. Am. Soc. Civ. Eng. 103, 115-134 (1977).

24. Lao, M. T. Leaching in greenhouses cultivation. in Crops: Growth, Quality and Biotechnology 406-431 (WFL Publisher Science and Technology, 2005).

25. Garcia-Caparros, P., Contreras, J. I., Baeza, R., Segura, M. L. \& Lao, M. T. Sustain. 9, 1-21 (2017).

26. Cabello, A. \& Cabrera, R. Consideraciones sobre la fertilización nitrogenada en los cultivos hortícolas de invernadero de Almería. (Junta de Andalucia. Consejeria de Agricultura y Pesca, 2003).

27. Reche, J. Agua, Suelo y Fertirrigación de Cultivos Hortícolas en Invernadero. (Ministerio de Medio Ambiente y Medio Rural y Marino, 2008).

28. Clune, S., Crossin, E. \& Verghese, K. J. Clean. Prod. 140, 766-783 (2017).

29. Juntti, M. \& Downward, S. D. Land use policy 66, 1-9 (2017).

30. Junta de Andalucía. Resultados de los Escenarios Locales Cambio Climático actualizados al $5^{\circ}$ Informe IPCC: evolución de los grupos climáticos y la temperatura. Escenarios Locales de Cambio Climático de Andalucía actualizados al $5^{\circ}$ Informe del IPCC" (ELCCA5) (2020). Available at:

http://www.juntadeandalucia.es/medioambiente/site/portalweb/menuitem.f497978fb79f8c75 7163ed105510e1ca/?vgnextoid=6e7a389d8f6d4310VgnVCM2000000624e50aRCRD. (Accessed: 11th March 2020)

31. Oteros-Rozas, E., Ruiz-Almeida, A., Aguado, M., González, J. A. \& Rivera-Ferre, M. G. Proc. Natl. Acad. Sci. U. S. A. 116, 26465-26473 (2019).

32. Petit, O. et al. Hydrogeol. J. 25, 1549-1564 (2017).

33. Custodio, E., Sahuquillo, A. \& Albiac, J. Sustain. Water Resour. Manag. 5, 11-26 (2019).

34. Tobi, R. C. A., Harris, F., Rana, R., Brown, K. A., Quaife, M., Green, R. Sustain. 11, 1-22 (2019).

35. European Commission. Consumer market study on the functioning of voluntary food labelling schemes for consumers in the European Union EAHC/FWC/2012 86 04. (2012).

36. Grunert, K. G., Hieke, S. \& Wills, J. Food Policy 44, 177-189 (2014).

37. Tait, P., Saunders, C., Guenther, M., Rutherford, P. \& Miller, S. Int. Food Res. J. 23, 1787-1796 (2016).

38. Hortidaily. Almeria's growers protest low prices and poor position. HortiDaily.com (2019).

39. COAG (Coordinadora de Organizaciones de Agricultores y Ganaderos). IPOD Índice de precios en origen y destino de los alimentos. (2020). Available at: http://coag.coag.org/post/ipod-indicede-precios-en-origen-y-destino-de-los-alimentos-122677. (Accessed: 15th September 2020)

40. Martínez-Valderrama, J. Ibáñez, J., Del Barrio, G., Sanjuán, M. E., Alcalá, F. J., Martínez-Vicente, S., Ruiz, A., Puigdefábregas, J.. Sci. Total Environ. 563-564, 169-178 (2016). 